\title{
FOSSIL SEALS FROM LATE NEOGENE DEPOSITS IN SOUTH AMERICA: A NEW PINNIPED (CARNIVORA, MAMMALIA) ASSEMBLAGE FROM CHILE
}

\author{
by STIG WALSH and DARREN NAISH
}

\begin{abstract}
A new monachine phocid pinniped assemblage from the north-central coast of Chile is described. The material was recovered from a marine bonebed of the Bahía Inglesa Formation which, based on macro- and microfossil evidence, is probably Late Miocene-Early Pliocene in age. At least two genera, Acrophoca and Piscophoca (both originally described from the Pisco Formation of Peru), are present. The Chilean material is significantly different from that of the two described species from the Pisco Formation and probably represents new species, though these are not named pending description of new material reported from Peru. The postcrania are morphologically intermediate between the northern Phocini and southern Lobodontini. The Bahía Inglesa Formation pinniped assemblage represents the first occurrence of fossil seals in Chile, and provides valuable information regarding the late Neogene radiation of monachines in the Southern Hemisphere. The occurrence of Acrophoca sp. in beds underlying a condensed MioPliocene bonebed suggests that these strata are no older than Late Miocene.
\end{abstract}

KEY WORDS: Pinnipedia, Neogene, Monachinae, Chile, biogeography, Acrophoca, Piscophoca.

Fossil mammals are well known in South America, and have been the subject of debate since the pioneering work of Charles Darwin (1891). South American Tertiary mammal faunas have been widely used in biostratigraphy (e.g. Marshall 1990; Wyss et al. 1994, 1996) and have also provided important information regarding the effects of climate change (e.g. Pascual and Jaureguizar 1990) and faunal interchange (e.g. Flynn and Wyss 1998). However, although Cenozoic deposits of Argentina (e.g. Muizon and Bond 1982; Muizon 1987) and Peru (Muizon 1981a, 1984, 1988; and authors in Pilleri 1989) have yielded diverse marine mammal faunas, most research has concentrated on terrestrial mammalian assemblages. Furthermore, despite early reports of fossil cetaceans in Chile (Darwin 1891), comparatively few studies (e.g. Donoso-Barros 1975; Dathe 1983; Salinas 1988; Valenzuela and Brito 1994) have documented occurrences of fossil marine mammals along the Chilean coast.

We provide here a preliminary report on the pinniped fauna of a new marine mammal assemblage from the Bahía Inglesa Formation on the north-central coast of Chile. This diverse fauna consists mainly of phocid pinnipeds, and mysticete and odontocete cetaceans. Teleost, chondrichthyan and avian taxa are also well represented (Walsh 1999; Walsh and Hume 2001), and chelonian and crocodyliform taxa are also present. Marine mammal remains (mainly articulated or associated skeletons of cetaceans) are infrequently encountered throughout the Bahía Inglesa Formation. However, the remains of marine mammals are far more abundant in a laterally extensive bonebed where they constitute around 48 per cent of the identified fossils observed in the field (total observations $=441$ ). At least 14 marine mammal species are represented in the bonebed, 12 of which are cetacean and two are pinniped. The true mammalian diversity is likely to be much higher, but due to the poorly diagnostic nature of much of the material, this current estimate is provisional. The cetacean and pinniped assemblage of the Bahía Inglesa Formation nevertheless represents the most diverse marine mammal fauna yet reported from Chile.

Pinnipeds, the sea lions, fur seals, walruses and seals, occur today in tropical, temperate and polar seas world-wide as well as in some Northern Hemisphere freshwater lakes. The 18-21 genera and 34 or so extant species belong to three clades, the interrelationships of which have proved controversial (King 1983; Wyss 1988; Berta and Wyss 1994; Bininda-Emonds et al. 1999). 
Otariids, the sea lions and fur seals, are widely distributed and occur in the North Pacific, the Arctic Ocean, around the coasts of South America, southern Africa and Australasia, and on most subantarctic islands. Odobenids, the walruses, survive as only a single species, Odobenus rosmarus. This inhabits the Arctic Ocean, the North Atlantic and North Pacific. Phocids, the true or earless seals, are represented today by two radiations. Phocine phocids, the northern seals, are restricted to cool and cold waters of the Northern Hemisphere. Monachine phocids, the monk, elephant and Antarctic seals, occur in all seas surrounding Antarctica and are also patchily distributed in the Northern Hemisphere with species present in the Mediterranean (Monachus monachus), around the Hawaiian islands (M. schauinslandi), and in the north-east Pacific (Mirounga angustirostris). A Caribbean species, Monachus tropicalis, may be extinct.

Some of the new material collected from Chile is clearly referable to the monachine phocid genera Acrophoca and Piscophoca, known from the Upper Miocene and Lower Pliocene of the Pisco Formation of Peru (Muizon 1981a). The Chilean specimens differ from the Peruvian taxa and probably represent new species. However, some of the differences may be a result of sexual or ontogenetic variation. Furthermore, four new pinniped genera together with three new species of Acrophoca have been collected from the Pisco Formation. These new taxa are represented by significant cranial and postcranial material (Muizon, pers. comm. 2000) and are presently being described. By comparison, the Bahía Inglesa material consists largely of isolated and fragmentary elements, and it would appear unwise to erect new taxa until more complete material has been recovered.

Much of the Bahía Inglesa material is similar to corresponding elements of either Acrophoca or Piscophoca, and tentative referral of some specimens to these genera is possible. Nonetheless, much of the material (such as vertebrae, ribs, sternal and flipper elements) is less diagnostic and is here referred to indeterminate Monachinae, Phocidae or Pinnipedia, depending upon the diagnostic potential of the material (cf. Good 1984).

Following recent work on the controversial status of the Monachinae, we provisionally regard this group as monophyletic but note that different tree typologies affect the content of the various monachine subgroups (see discussion). For the sake of clarity we follow the traditional terminology for monachine subgroups (Scheffer 1958; King 1983; Muizon 1981a, b, 1982; Bonner 1989), but feel that clarification is required in view of McKenna and Bell's (1997) taxonomic scheme where Monachinae is renamed Monachini. Monachinae as used here includes Monachini (Monachus and similar taxa), Miroungini (Mirounga and similar taxa) and Lobodontini (Antarctic monachines). In order to distinguish between Monachinae and Monachini, the former are referred to as monachines, the latter monachins. For consistency we refer to members of the Lobodontini as lobodontins. The genus Monotherium would appear to be a taxonomic dumping ground for various different kinds of basal monachines (and other phocids) and hence species other than M. aberratum, the type species (Van Beneden 1877), are referred to here as 'Monotherium'.

The specimens described here are accessioned to the collections of the Muséum national d'Histoire naturelle, Paris, and are identifiable by the prefix MNHN CHL (Chile). Institutional abbreviations used in text: MNHN, Muséum national d'Histoire naturelle, Paris; BMNH, The Natural History Museum, London; SMNK, Staatliches Museum für Naturkunde, Karlsruhe, Germany. Nomenclature used follows Wyss (1988), although we adopt the terms 'cranial' and 'rostral' for anterior, and 'caudal' in place of posterior.

\section{SITE LOCATION}

The Bahía Inglesa Formation crops out in an area of arid badlands 1 km inland of Bahía Inglesa bay, on the coast of north-central Chile. The closest settlement is the fishing village of Bahía Inglesa, and the nearest town is Caldera, some $5 \mathrm{~km}$ and $10 \mathrm{~km}$ north-east of the study area respectively (Text-fig. 1A). The study area occupies an elongate area from approximately $\mathrm{S} 27^{\circ} 06^{\prime} 43 \cdot 5^{\prime \prime}$, W70 $50^{\prime} 09 \cdot 8^{\prime \prime}$, and $\mathrm{S} 27^{\circ} 09^{\prime} 58 \cdot 6^{\prime \prime}$, $\mathrm{W} 70^{\circ} 52^{\prime} 32 \cdot 4^{\prime \prime}$.

\section{GEOLOGY}

The study area is structurally complex owing to its proximity to active subduction in the Peru-Chile Trench. The marine Bahía Inglesa Formation (Text-fig. 1B) was first described by Rojo (1985) and consists 

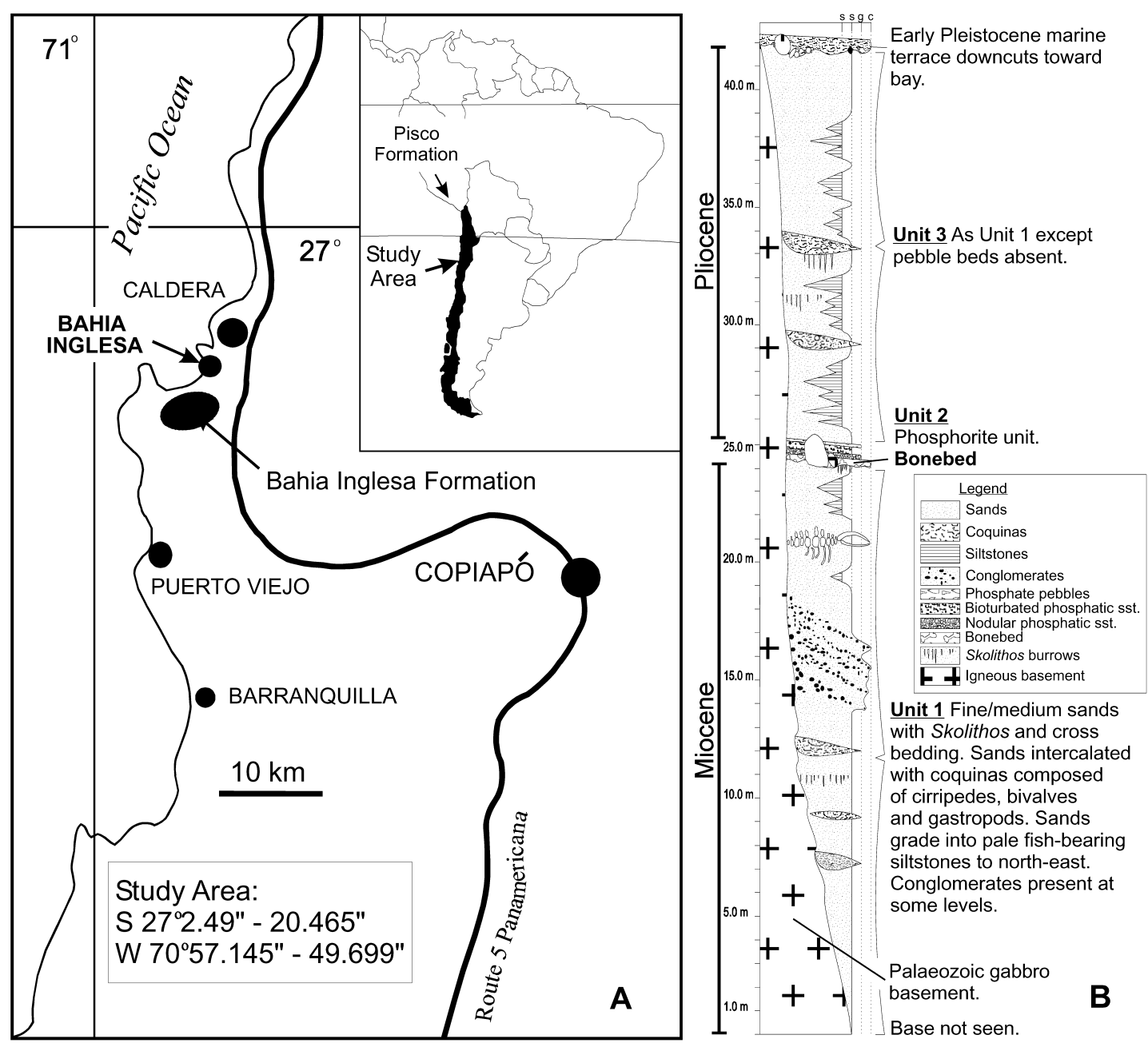

TEXT-FIG. 1. Location and stratigraphy of the Bahía Inglesa Formation. A, location of site relative to the Pisco Formation (Peru). B, composite stratigraphic log of the Bahía Inglesa Formation.

of over $42 \mathrm{~m}$ of siltstones, fine sands, shelly coquinas, pebble beds, and a phosphatite bonebed (Walsh 1999). The sediments were deposited into a series of grabens formed in the Palaeozoic gabbroic basement (Rojo 1985). This basement is visible today as a series of roughly NE-SW-trending outcrops in the study area. Beds of well-rounded gabbro pebbles onlap these outcrops suggesting that they were at least partially emergent throughout much of the depositional history of the site. Penguin remains are abundant in the bonebed, suggesting that these outcrops formed islands that were used by the birds as island habitats (Walsh and Hume 2001).

The phosphatite bonebed has a lateral extent of around $4.0 \mathrm{~km}^{2}$. It occurs at the base of four layers of hard phosphatic arkose. The basal layer rarely exceeds $0.2 \mathrm{~m}$ in thickness but is the most fossiliferous, and most of the material described in this work was derived from this layer.

A series of NW-SE-trending reverse faults displace Miocene and Pliocene strata, indicating that the primarily extensional stress field of the late Neogene was replaced by compression no earlier than the end of the Pliocene. During this period, successive jacking of the seafloor resulted in the formation of a series 
of marine terraces, and the molluscan assemblage of the oldest terrace indicates that final emergence of the formation probably occurred sometime during the Pleistocene.

\title{
AGE OF THE BAHÍA INGLESA FORMATION
}

The final marine terrace deposit at the top of the sequence (Text-fig. 1B) contains a molluscan assemblage that includes Argopecten purpuratus, Crepidula dilatata, Mulinia edulis, Oliva peruviana and Trochita trochiformis (for a comprehensive account of the molluscan fauna of the formation, see Herm 1969). This terrace assemblage indicates an early Pleistocene age for the top of the succession, but as these are extant species it is not useful in constraining a youngest age for this horizon.

The unit overlying the bonebed (Unit 3, Text-fig. 1B) has been well dated on the basis of diatoms (Tsuchi et al. 1988) and foraminiferans (Ibaraki 1995) at between 4.5 and 2.6 Ma. In addition, Long (1993) described a chondrichthyan assemblage from this unit, and noted the presence of teeth of the shark Carcharodon carcharias, but absence of the teeth of Cosmopolitodus hastalis supported a Pliocene age for the unit (following Venglinskiy 1989 we regard this species as a member of Cosmopolitodus Glyckman, 1964, rather than Isurus). The teeth of these sharks are used in the Neogene of the South American Pacific as zonal indicators (e.g. Muizon and DeVries 1985; Long 1993), where Cosmopolitodus hastalis is last observed at the top of the Miocene and Carcharodon carcharias first appears at the base of the Pliocene.

Possibilities for dating the bonebed are restricted because calcareous fossils are absent, and siliceous microfossils are fragmentary and extremely rare. The presence of Carcharocles megalodon ( = Carcharodon giganteus) led Rojo (1985) to regard the bonebed as Miocene. However, Cosmopolitodus hastalis and Carcharodon carcharias are also present in the bonebed (Walsh 1999), indicating that this unit must represent a condensed sequence that spans both the Miocene and Pliocene. However, the diatom age of Tsuchi et al. (1988) indicates that the bonebed can be no younger than middle Pliocene, and is probably slightly older than this as the diatomite sampled by Tsuchi et al. (1988) came from near the top of Unit 3, several metres above the bonebed. In addition, the teeth of Cosmopolitodus hastalis are the most abundant shark teeth in the bonebed, whilst those of Carcharodon carcharias are comparatively rare. The relative abundance of these shark teeth suggests that this condensed horizon does not extend very far into the Pliocene.

As the bonebed contains Cosmopolitodus hastalis teeth, sediments underlying the bonebed must be Miocene. The presence of a monachine pinniped (see below) in Unit 1 (Text-fig. 1B) indicates that the top of this unit is probably no older than Middle Miocene, as this is the age of the first recognizable monachine (Muizon 1982). However, as the first occurrence of Acrophoca sp. (Muizon and DeVries 1985) in Peru is Late Miocene, the top of this unit is, therefore, unlikely to be older than Late Miocene.

\author{
SYSTEMATIC PALAEONTOLOGY \\ PINNIPEDIA Illiger, 1811 \\ PHOCIDAE Gray, 1825 \\ MONACHINAE Gray, 1869
}

Genus ACROPHOCA Muizon, 1981a

Figs 1-7. Material referred to Acrophoca sp. 1, left rib (MNHN CHL25) in caudal aspect. 2, left metatarsal 2 (MNHN CHL22) in lateral aspect. 3, axis (MNHN CHL20) in left lateral aspect. 4, ?cervical vertebra (MNHN CHL23) in dorsal aspect. 5, mandibular ramus (MNHN CHL5) in medial aspect. 6, left tibia (MNHN CHL31) in caudal aspect. 7, skull fragment (MNHN CHL24) in dorsal aspect. All specimens $\times 1$. 
PLATE 1

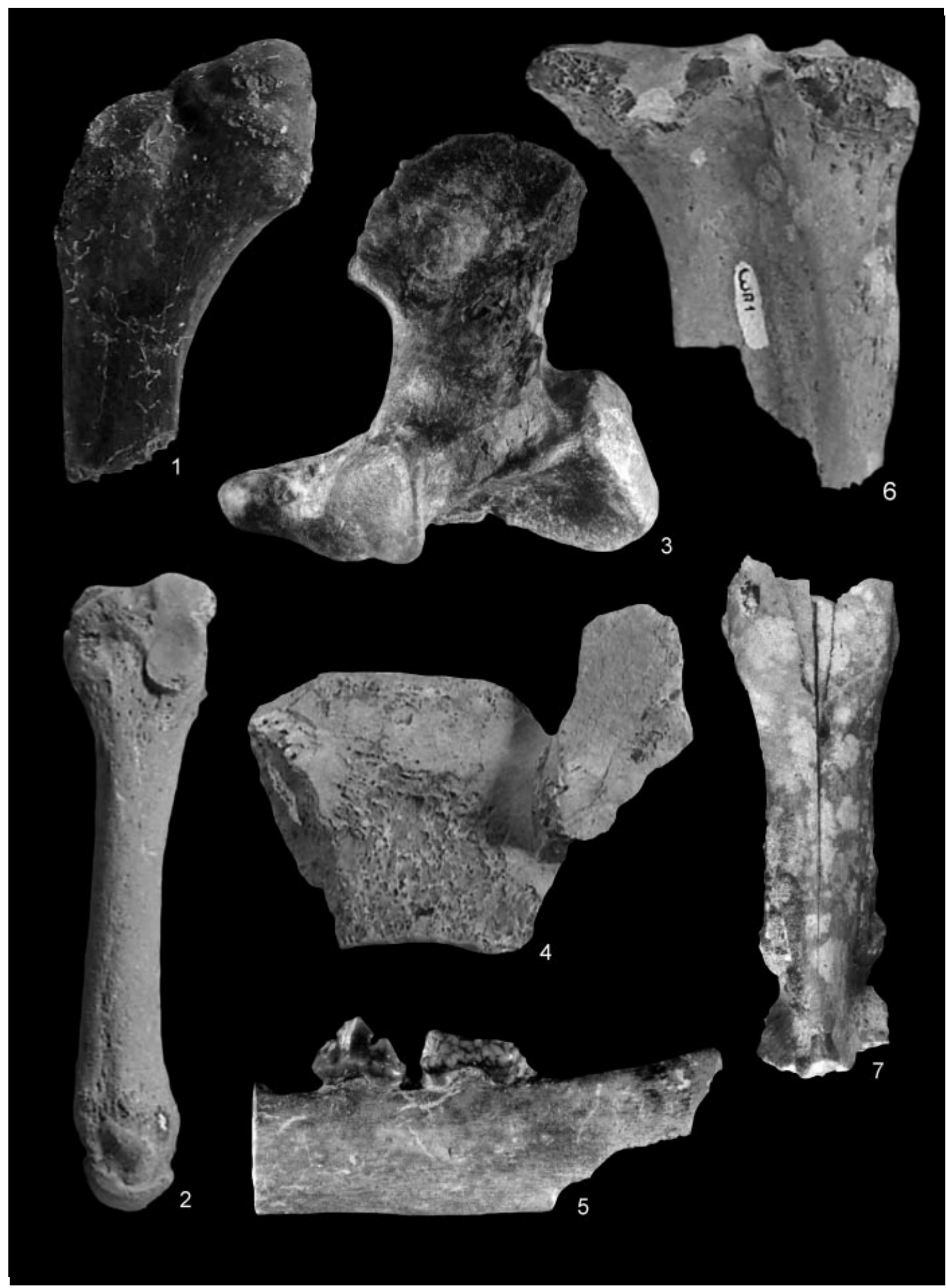

WALSH and NAISH, Acrophoca 


\title{
Acrophoca sp.
}

Plate 1, figures $1-7$, Text-figures $2-3$

\begin{abstract}
Material. Interorbital region of skull (MNHN CHL24), right mandibular ramus (MNHN CHL5), right tibia (MNHN CHL31), cervical(?) vertebra (MNHN CHL23), metatarsal II (MNHN CHL22), left rib (MNHN CHL25), axis (MNHN CHL20).
\end{abstract}

Locality and horizon. MNHN CHL22-25 and 31 were collected from Unit 1 several metres below the bonebed. These specimens were found within $1 \mathrm{~m}$ of each other together with an associated skeleton of a small odontocete cetacean, and elements referable to an istiophorid teleost and a spheniscid. The in situ nature of the cetacean skeleton indicates that this assemblage was not derived from the bonebed, and the possibility exists that MNHN CHL22-25 and 31 are from the same individual. The stratigraphic position of this site indicates that these specimens are Late Miocene. MNHN CHL5 and 20 were collected from the bonebed and can, therefore, only be assigned an age of Late MioceneEarly Pliocene.

\section{Description}

Mandible. MNHN CHL5 (Pl. 1, fig. 5; Text-fig. 2A-C) comprises a fragment of right mandibular ramus $66 \mathrm{~mm}$ long, $19 \mathrm{~mm}$ deep, and $9 \mathrm{~mm}$ mediolaterally at its widest point. Matrix covers much of the lateral surface including the lateral surface of $\mathrm{M}_{1}$. The specimen includes $\mathrm{P}_{4}$ and $\mathrm{M}_{1}$, but is missing all bone caudal to a vertical break $27 \mathrm{~mm}$ caudal to $\mathrm{M}_{1}$, and from the rostral margin of the caudal alveolus for $\mathrm{P}_{3}$. The teeth lack the grooved enamel often present on the dentition of juvenile phocids but are otherwise unworn, suggesting that the specimen was a young adult.

Laterally, the ramus has the shallow dorsoventral height and pronounced diastema between the post-canines of Acrophoca (Muizon 1981a). However, it is slightly smaller than any mandible of A. longirostris examined, and the diastema between $\mathrm{P}_{4}$ and $\mathrm{M}_{1}$ is smaller than in that species. This suggests that the lower jaw was shorter than in $A$. longirostris. In contrast to A. longirostris, the ramus of MNHN CHL5 is mediolaterally thinner and its dorsal margin caudal to $\mathrm{M}_{1}$ is not concave in lateral aspect. In dorsal view, the ramus is slightly sigmoidal with a medially directed curve caudally and a laterally directed curve rostrally. This curvature indicates that the mandible must have been narrow rostrally, as in A. longirostris. A large oval foramen $(6 \times 3 \mathrm{~mm})$ is situated on the dorsalmost region of the lateral surface, below the caudal alveolus for $\mathrm{P}_{3}$. This foramen is absent from A. longirostris.

The two post-canines are twin-rooted, tricuspate, labio-lingually compressed, triangular in lateral view, and are lowcrowned, with a similar length/height ratio (1.4) to A. longirostris. The best-preserved tooth, $\mathrm{P}_{4}$, differs somewhat from that of A. longirostris. Although most authors have recognised that assigning cusp homologies to phocid post-canines is problematic (e.g. Muizon and Hendey 1980; Bininda-Emonds and Russell 1996), we provisionally name the three main cusps here for ease of description. In CHL5, a protoconid, paraconid and metaconid are well developed, and accessory cusps are present but poorly developed. In A. longirostris, the paraconid is much reduced, and the metaconid only very weakly developed. Accessory cusps do not appear to have been present. This is a characteristic monachine crown morphology (King 1972). $\mathrm{P}_{4}$ is set slightly obliquely but as the alveolar pattern indicates a tooth row aligned with the long axis of the ramus (as in A. longirostris), this may be an artefact of preservation. The protoconid of $\mathrm{M}_{1}$ is damaged, but that of $\mathrm{P}_{4}$ is positioned labially relative to the paraconid and metaconid. A concavity is developed on the lingual occlusal surface and the labial surface is convex. This results in a lingually directed curvature of the crown in rostral view.

Although similar to A. longirostris, the dentition of MNHN CHL5 is more similar to the extant Monachus shauinslandi (Hawaiian monk seal) in the number, positioning and shape of the cusps (Text-fig. 2F-I). However, the teeth of MNHN CHL5 differ from M. shauinslandi in that the crown is more laterally compressed, the rostral and caudal accessory cusps are reduced, and the protoconid is taller, wider and distinctly diamond-shaped in lateral aspect; in $M$. shauinslandi, the protoconid is triangular.

Axis. This specimen (MNHN CHL20; Pl. 1, fig. 3; Text-fig. 2D-E) is almost complete, but has sustained damage to the neural arch, spine and lateral processes. This element appears to be indistinguishable from that of A. longirostris, exhibiting the markedly elongate centrum of that species (Muizon 1981a). In lateral aspect, the specimen is equant, but would have been taller than long when the neural spine was complete. The odontoid process is narrow and angled dorsally, and the cranial articular facets are small, oval, and directed craniolaterally at approximately 45 degrees. The caudal articular facet has a slightly larger diameter than the neural canal, and is directed slightly dorsally, more so than in Piscophoca pacifica. As in lobodontins, a narrow keel is developed on the ventral surface of the centrum. This thickens caudally, resulting in the rounded triangular shape of the caudal articular facet. 


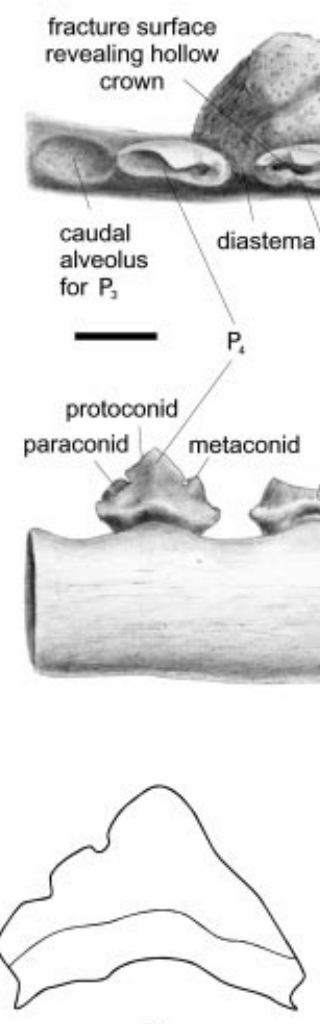

$\mathrm{F}$

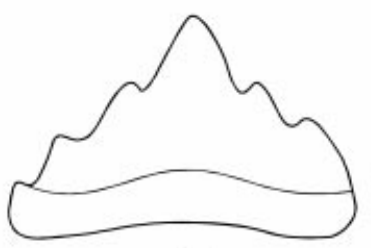

G

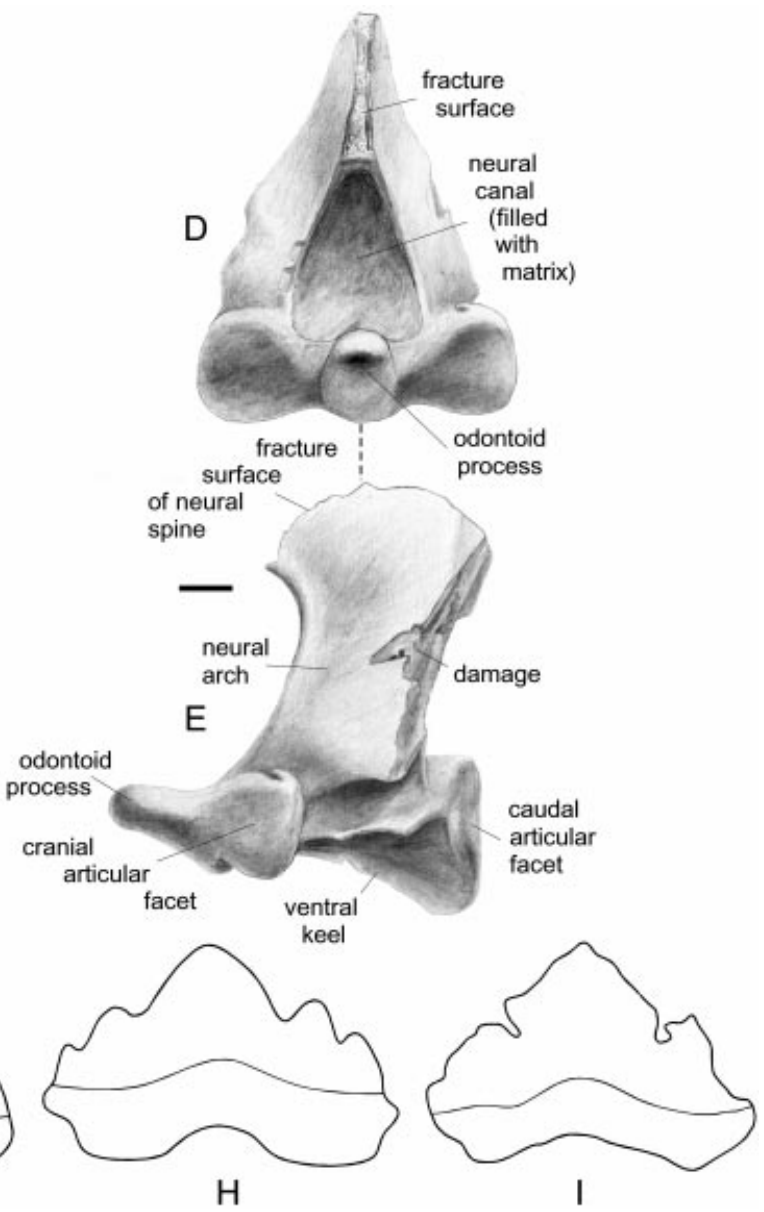

TEXT-FIG. 2. Acrophoca sp. material. Mandibular ramus (MNHN CHL5) in A, occlusal, B, rostral and C, lateral aspects. Axis vertebra in D, cranial, and E, lateral aspects. F-I, scaled outline representations of monachine $\mathrm{P}_{4}$ in lingual aspect. F, Acrophoca longirostris (MNHN PPI60). G, Monachus monachus (BMNH 1934.8.5.4). H, M. shauinslandi (BMNH 1958.11.26.1). I, MNHN CHL5. Scale bars represent $10 \mathrm{~mm}$.

The following specimens are thought to belong to the same individual.

Fragment of skull. MNHN CHL24 (Pl. 1, fig. 7; Text-fig. 3A-C) is a distinctive, laterally compressed interorbital portion of skull, measuring $75 \mathrm{~mm}$ long, $25 \mathrm{~mm}$ wide and $28 \mathrm{~mm}$ deep. The specimen is missing all areas of bone rostral to the nasal/frontal symphysis, caudal to the postorbital widening of the braincase, and the entire rostral region. It is weathered but otherwise uncompressed and well preserved. All sutures are distinct but fully fused, suggesting that the animal was adult. The nasals extend caudally between the frontals, a condition diagnostic of the Phocidae (King 1983), and the extremely narrow triangle formed by the caudal nasals in this region is exactly like that found in $A$. longirostris. This specimen is very similar in size and morphology to the same region in A. longirostris, particularly in the length of the interorbital region. There are, however, some differences.

The dorsal surface of the antorbital region of the frontals is flat and a rounded corner is formed where the flat dorsal surface meets the vertical lateral surface of the frontal. The dorsal surface curves gradually into the lateral surface in all Acrophoca skulls examined, including that of A. longirostris and other undescribed species of Acrophoca held in the MNHN collections (Walsh, pers. obs.).

A narrow sagittal crest is present in A. longirostris and extends from the occipital crest to the mid-orbital region. The sagittal crest does not extend as far rostrally as the orbital region in MNHN CHL24 and may have been completely 

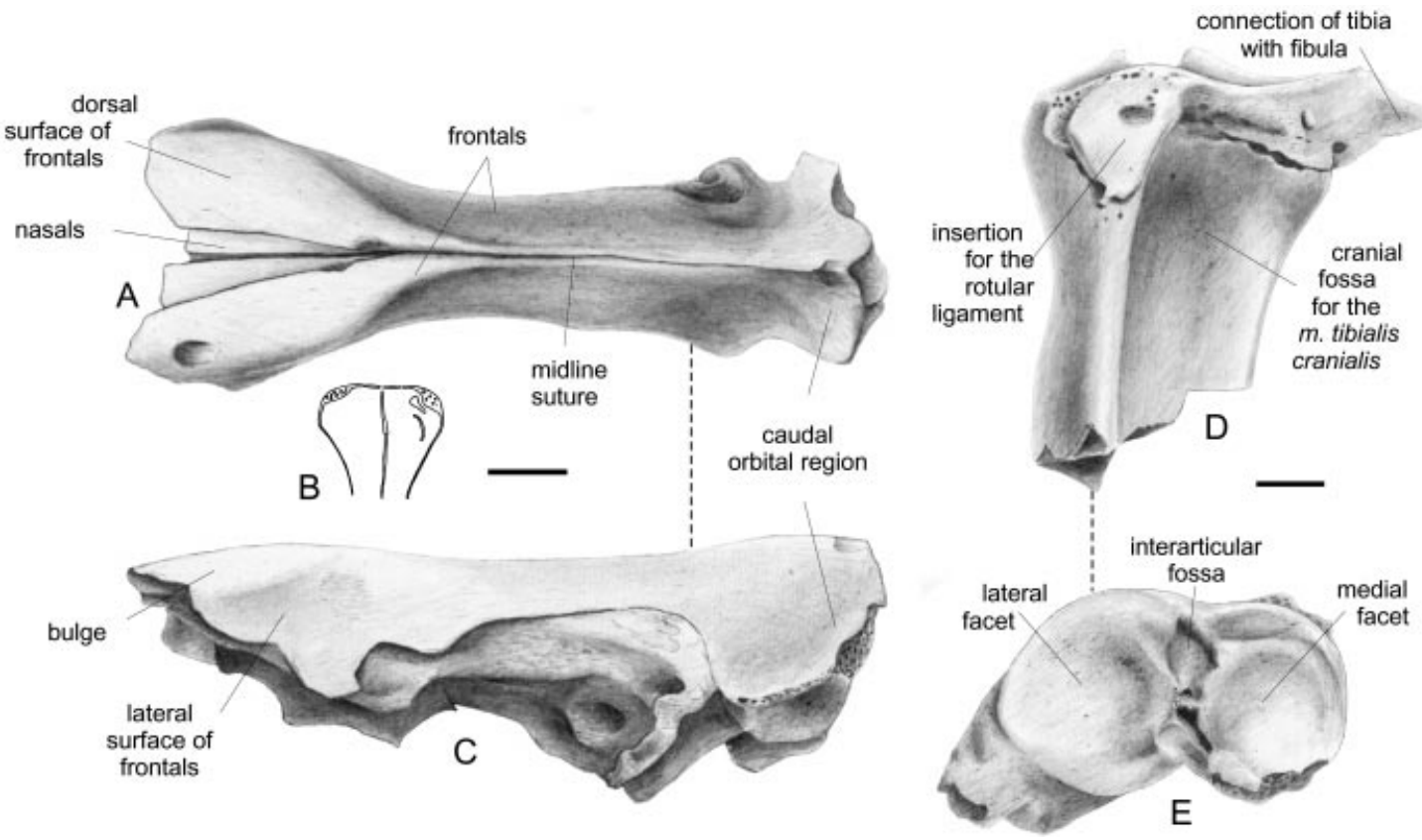

TEXT-FIG. 3. Acrophoca sp. material. A, skull fragment (MNHN CHL24) in dorsal aspect. B, unscaled schematic representation of rostral view, and C, lateral aspect. Right tibia (MNHN CHL31) in D, cranial, and E, proximal aspects. Scale bars represent $10 \mathrm{~mm}$.

absent, though this cannot be determined. The crest has not been removed by damage in MNHN CHL24 and its absence may be a result of sexual dimorphism or ontogeny. This crest is better developed in A. longirostris than in any other fossil monachine taxon, and was regarded by Muizon $(1981 a, 1982)$ as an apomorphy separating Acrophoca and Hydrurga from other members of the Lobodontini.

Tibia. MNHN CHL31 (Pl. 1, fig. 6; Text-fig. 3D-E) consists of the proximal portion of a right tibia some $63 \mathrm{~mm}$ in length. The fibula is absent but the tibia retains the fibular symphysis below the epiphysis. Although slightly weathered, the specimen is otherwise in good condition. The tibia and fibula were fused proximally, as in all phocids except M. shauinslandi (Wyss 1988; Bininda-Emonds and Russell 1996), and the tibia displays a slight sigmoidal curvature of its diaphysis. The proximal articulatory facets are concave as in A. longirostris and other members of the Lobodontini, and the lateral facet is 1.2 times the width of the medial facet. Unlike A. longirostris, the plane of the articular face is directed almost perpendicular to the long axis of the diaphysis, resulting in a somewhat square proximal end. By comparison, the proximal epiphysis of A. longirostris is angled toward the fibula, such that the head of the fibula is lower than the medial articulatory facet (Muizon, 1981a; Walsh, pers. obs.). The insertion for the rotular ligament is a well-defined and prominent, inverted, equilateral triangle that extends from the proximal margin of the epiphysis to $9 \mathrm{~mm}$ distal of the epiphyseal/diaphyseal symphysis. This insertion is the same shape as A. longirostris, but somewhat shorter than in that species, and more like that of Homiphoca. Both the cranial and caudal tibial fossae are deep, suggesting strong development for the $\mathrm{m}$. tibialis cranialis and caudalis. The cranial fossa in A. longirostris is shallower and broader.

Metatarsal 2. This specimen (MNHN CHL22; Pl. 1, fig. 2) is complete and, although weathered, is otherwise in good condition. The metatarsal can be referred to the Monachinae on the basis of the smooth, ridge-less distal articulation (King 1966; Wyss 1988). Pinniped metatarsals are poorly diagnostic at generic level. The specimen is, therefore, tentatively assigned to Acrophoca only because of its association with MNHN CHL24 and the other pinniped material from this site. However, this specimen appears to be proportionally longer than the metatarsals of A. longirostris (Muizon, pers. comm. 2001). 
Cervical(?) vertebra. MNHN CHL23 (Pl. 1, fig. 4) is in very poor condition, and consists of the centrum and a damaged left postzygapophysis. Measuring $41 \mathrm{~mm}$ in length and $53 \mathrm{~mm}$ in width, this specimen is slightly smaller than the equivalent element in an adult A. longirostris. It is too poorly preserved for useful description, and is tentatively referred to Acrophoca only because of its association with MNHN CHL24.

Rib. MNHN CHL25 (Pl. 1, fig. 1) is the proximal portion of a left rib, weathered only on the cranial surface. Owing to the poor diagnostic potential of ribs, this specimen is again tentatively referred to Acrophoca only because of its association with MNHN CHL24.

Genus PISCOPHOCA Muizon, $1981 a$

Piscophoca aff. pacifica

Plate 2, figures 1-10; Text figures 4-5

Material. Left mandibular ramus (MNHN CHL41), left scapula (MNHN CHL32), right scapula (MNHN CHL33), left ulna (MNHN CHL19), two right femora (MNHN CHL17-18), left astragalus (MNHN CHL37), two right astragali (MNHN CHL36, 39), left calcaneum (MNHN CHL35), atlas (MNHN CHL34).

Locality and horizon. All specimens were collected from the bonebed, but MNHN CHL41 (ramus), MNHN CHL34 (atlas), MNHN CHL39 (astragalus), and MNHN CHL40 (humerus) were collected from within $5 \mathrm{~m}$ of each other (S27 $09^{\prime} 18 \cdot 5^{\prime \prime}$, W7 $70^{\circ} 53^{\prime} 00 \cdot 1^{\prime \prime}$, determined by Garmin 38 GPS). Pinniped remains are comparatively common at this collection point, but the sedimentary character of the bonebed renders any inference of association dubious. No other material referable to Piscophoca has been recovered from units under- or overlying the bonebed and, at present, the specimens can only be tentatively assigned an age of Late Miocene-Early Pliocene.

\section{Description}

Mandibular ramus. MNHN CHL41 (Pl. 2, fig. 1; Text-fig. 4A-B) is a left ramus measuring $115 \mathrm{~mm}$ long by $30 \mathrm{~mm}$ deep, and with a mediolateral thickness of $16 \mathrm{~mm}$. The surface preservation of this specimen is good, but it is missing the caudalmost portion, including the coronoid process. The only tooth present is $\mathrm{C}_{1}$, and it has sustained damage to the crown. Matrix fills the alveolar cavities, and is present as patches on the medial surface. The ramus is a robust element in that it is deep and somewhat mediolaterally thickened. In caudal view, the ramus exhibits significant torsion, with a laterally directed twist at the mandibular symphysis, and a medially directed twist near the caudal fracture surface. In lateral aspect, the rostral margin of the mandibular symphysis is rounded and curves gradually into the ventral margin. The dorsal margin immediately caudal of the alveolus for $\mathrm{M}_{1}$ is concave in this view, unlike the mandibular ramus of Homiphoca, which is otherwise similar in shape. Some of the characters diagnostic of $P$. pacifica relate to the caudal portion of the ramus, but although these features are missing in MNHN CHL41 because of damage, the narrow shape and depth of the rostral region of the fossa for the m. masseter pars profundus is the same as that seen in A. pacifica. However, the specimen can still be referred to Piscophoca on account of its overall morphology and the extreme shortness of the mandibular symphysis, which extends only as far the caudal margin of the rostral alveolus for $\mathrm{P}_{2}$, as in P. pacifica. Such short symphyses have been considered diagnostic of the Monachinae (Hendey and Repenning 1972), but probably represent a trend within this group (Muizon 1981a). Nevertheless, the short symphysis of Piscophoca is distinctive, and the presence of an almost identical symphysis on this specimen strongly supports its inclusion in that genus.

However, MNHN CHL41 differs from P. pacifica in the following features. The region of the bone around the alveolus for $\mathrm{C}_{1}$ is flared rostrolaterally, similar to the condition in the extant M. monachus. The alveolus for $\mathrm{P}_{1}$ in MNHN CHL41 is almost as large as that of $\mathrm{C}_{1}$, and therefore the canine is smaller and the first post-canine is larger than in $P$. pacifica. The alveolus for $\mathrm{P}_{1}$ is contiguous with that of $\mathrm{C}_{1}$ unlike $P$. pacifica, where there is a significant diastema between the two alveoli. Therefore, although the caudal margin of the mandibular symphysis is level with the caudal margin of the alveolus for $\mathrm{P}_{1}$ (as in $P$. pacifica), the mandibular symphysis is appreciably shorter than in that species due to the rostral position of $\mathrm{P}_{1}$. The alveoli for $\mathrm{I}_{1}$ and $\mathrm{I}_{2}$ are round, unlike $P$. pacifica where the alveolus for $\mathrm{I}_{2}$ is narrow and oval.

Atlas. MNHN CHL34 (Pl. 2, fig. 4) is a largely complete atlas vertebra, but has sustained damage to most of the prominent features and is covered by matrix in the neural canal and on the cranial and caudal surfaces of the transverse 


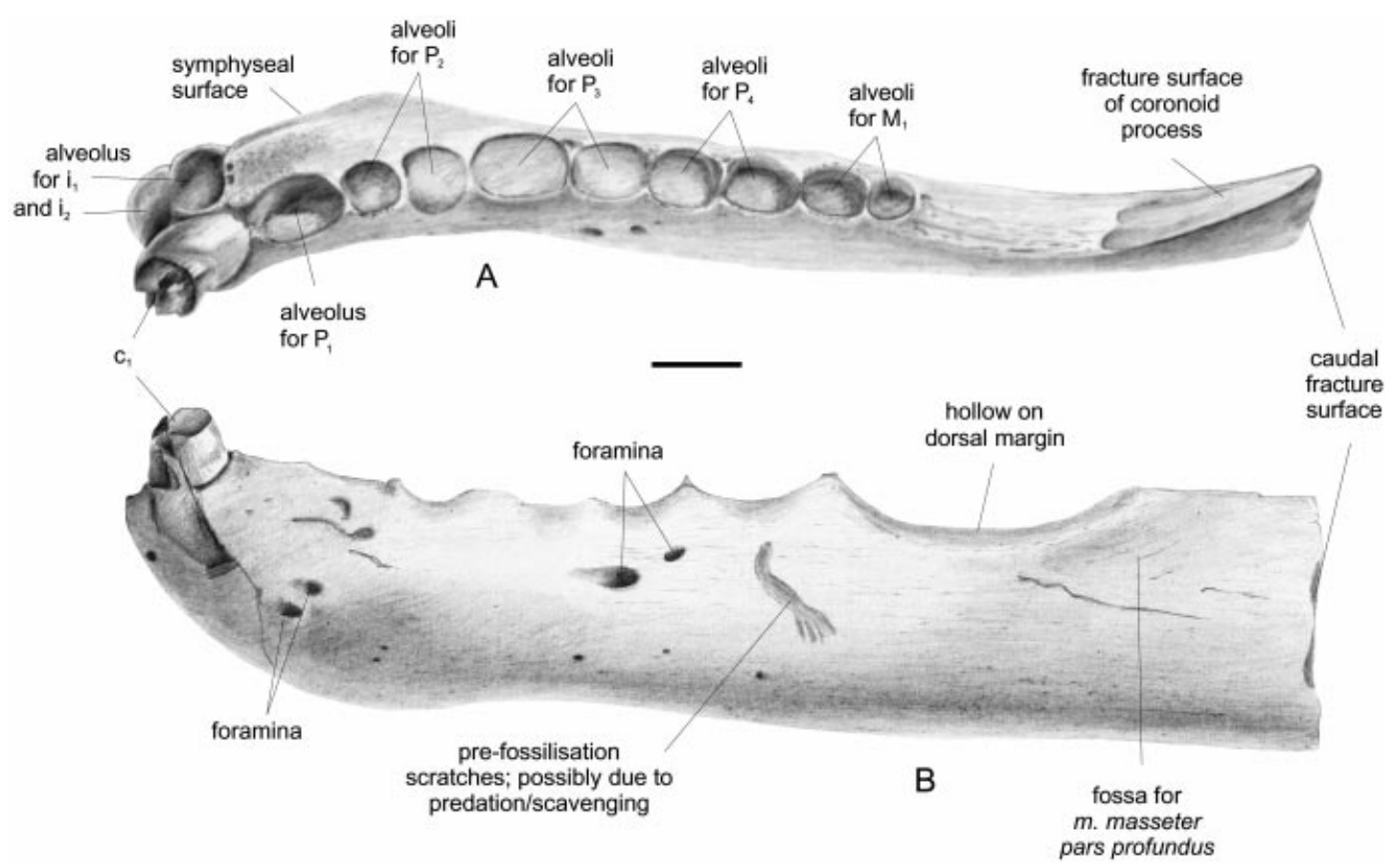

TEXT-FIG. 4. Piscophoca sp. left mandible (MNHN CHL41) in A, occlusal, and B, lateral aspects. Scale bar represents $10 \mathrm{~mm}$.

processes. This element is tentatively referred to Piscophoca because of size and morphology. Furthermore, the element can be distinguished from that of Acrophoca by the position of the transverse foramen, which in that genus is closer to the dorsal margin than in Piscophoca, and because the vertebral body is proportionately craniocaudally shorter than in Acrophoca. One notable feature is that, as in phocines, Monachus, Acrophoca and Piscophoca, the transverse foramen is visible in caudal view (King 1966; Wyss 1988). In extant lobodontins, this foramen is only visible in dorsal aspect.

Scapula. MNHN CHL33 (Pl. 2, fig. 5) is a fragment of right scapula represented by the caudalmost margin including the glenoid region. The medial side is obscured by matrix. MNHN CHL32 (Pl. 2, fig. 6) is a fragment of a left scapula consisting of the glenoid region missing the cranial, caudal and dorsal margins, and also has its medial side obscured. These specimens are referred to Piscophoca as they are indistinguishable from the scapulae of P. pacifica. Because it is damaged, it is not possible to judge whether the caudal angle of the teres major process was close to 90 degrees as it is in monachines (e.g. Wyss 1988). However, the origin of the scapular spine is within the caudal quarter of the blade, indicating that the supraspinous fossa was large as it is in monachines (King 1983; Wyss 1988). The acromion process is missing, but the base of the spine appears to have been narrow. The width of the spine, and its position relative to the caudal margin of the blade are as seen in P. pacifica. In P. pacifica, the caudal margin of the blade is straight in lateral

\section{EXPLANATION OF PLATE 2}

Figs 1-10. Material referred to Piscophoca sp. 1, left mandible (MNHN CHL41) in lateral aspect. 2, left astragalus (MNHN CHL37) in lateral aspect. 3, right astragalus (MNHN CHL36) in medial aspect. 4, atlas vertebra (MNHN CHL34) in ventral aspect. 5, right scapula (MNHN CHL33) in lateral aspect. 6, left scapula (MNHN CHL32) in lateral aspect. 7, right femur (MNHN CHL18) in caudal aspect. 8, right femur (MNHN CHL17) in cranial aspect. 9, left calcaneum (MNHN CHL35) in dorsal aspect. 10, left ulna (MNHN CHL19) in lateral aspect. All specimens $\times 0 \cdot 6$. 
PLATE 2

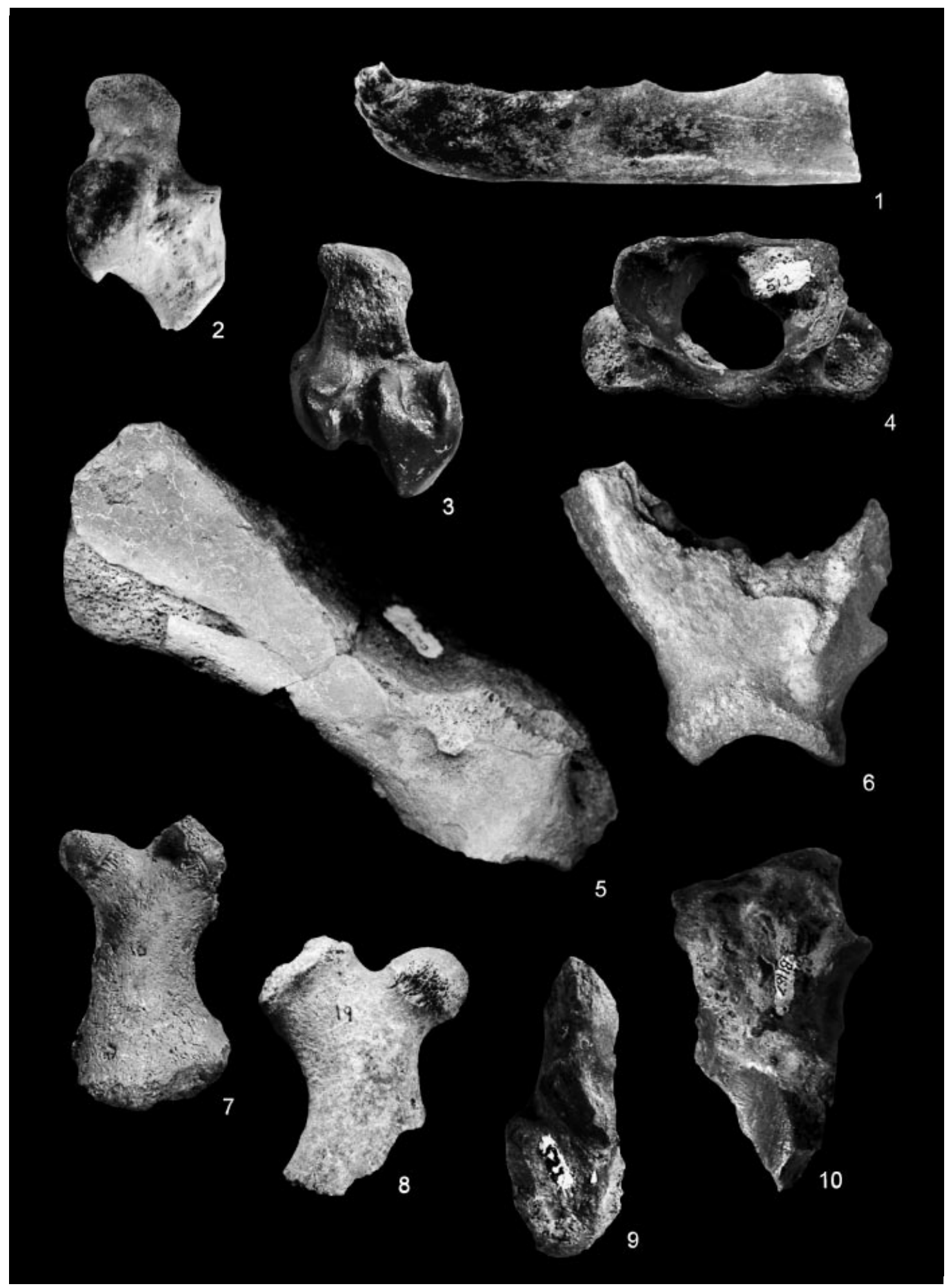

WALSH and NAISH, Piscophoca 
aspect and the caudal margin is triangular in cross-section as in Monachus, but unlike Acrophoca and the other Lobodontini, where it is rounded in section (Muizon 1981a). The insertion for the m. triceps brachii is triangular, flat, and angled craniolaterally, as in P. pacifica. The glenoid facet is wide and deeply concave, indicating a wide range of movement for the forelimb.

Ulna. MNHN CHL19 (Pl. 2, fig. 10) is a proximal ulna missing the distal end and mainly covered by matrix. This specimen is indistinguishable from the same region in $P$. pacifica. The diaphysis is mediolaterally compressed and thin, the trochlear notch is wide, and the articulatory surface indicates a wide range of axial and lateral movement. The supra-trochlear surface of the cranial margin is distinctly concave. The preserved region differs from $P$. pacifica in only one respect; the surface for the $\mathrm{m}$. anconeus lateralis is trapezoidal and extends from the distal margin almost to the mid-line of the trochlear notch. In P. pacifica, this surface is an irregular oval that extends to the distal margin of the trochlear notch.

Femur. Two right femora are referred to Piscophoca (P1. 2, figs 7-8; Text-fig. 5A-B). Although both specimens (MNHN CHL17-18) are poorly preserved and generally worn, they were clearly short and wide, and can be confidently referred to the Phocidae as they lack a lesser trochanter (Muizon 1982; King 1983; Wyss 1988). Comparison with $P$. pacifica is limited because the femur of that species is known only from a referred fragment (MNHN SAS501). However, the preserved region of the femur of $P$. pacifica bears a distinct sub-trochanteric fossa on the caudal surface. Such a fossa is present on the femora of most phocines and, although generally absent in extant monachines (except Lobodon carcinophagus), it is present in many fossil monachines (Muizon and Hendey 1980; Muizon 1982). The fossa is present on MNHN CHL17 and 18, and its absence from the femur of Acrophoca is sufficient to indicate that these specimens are not referable to that genus. Due to the presence of this character, MNHN CHL17 and 18 are, therefore, both tentatively referred to Piscophoca, pending the discovery of associated material.

MNHN CHL17 consists of a proximal portion, missing the distal part of the diaphysis including the distal condyles. MNHN CHL18 is more complete, but the cranial surface is covered by matrix and the distal condyles are worn. The sub-trochanteric fossa is shallow, but occupies around half the width of the greater trochanter. The greater trochanter is damaged on both specimens, but is broad and on each appears to have risen slightly higher dorsally than the caput. This condition is more typical of Northern Hemisphere phocids (Phocinae), although it is also present in Acrophoca. The caput on both specimens is damaged but was clearly spherical and connected to the diaphysis by a distinct neck. The distal region of the cranial surface of MNHN CHL17 bears a shallow concavity, as in Homiphoca and many of the Lobodontini (Muizon 1982). In MNHN CHL17, the fossa for insertion of $\mathrm{m}$. pectineus is deep. The epicondylar crest is somewhat straight in MNHN CHL18, and extends from the proximal extent of the distal condyles halfway to the proximal extent of the caput.

Astragalus. One left (MNHN CHL36) and two right (MNHN CHL37, 39) astragali were collected (Pl. 2, figs 2-3; Text-fig. 5C-D). The presence of a well-developed and elongate caudal process clearly indicates the phocid affinities of these specimens (Muizon 1982; King 1983; Wyss 1988). All of these astragali are in good condition, although each has sustained slight damage to the caudal process, and large areas of MNHN CHL39 (not figured) are covered by hard matrix. The ectal and sustentacular facets on the lateral surface of the astragali are both narrow and divided by an equally narrow interarticular sulcus. The sustentacular facet is long as in phocines, Monachus and referred specimens of P. pacifica, and unlike that of all other extant monachines, Acrophoca, Homiphoca and 'Monotherium' (Wyss 1988; Muizon, pers. comm. 2001). This condition is particularly like that of M. monachus, in which the sustentacular facet is both long and narrow. We note the problematical polarity and distribution of this character state within phocines and monachines (King 1966; Wyss 1988).

The tip of the caudal process in MNHN CHL39 is missing, but in MNHN CHL36 and 37 the height/width ratio is 0.66 (s.d. = 0.02). The Bahía Inglesa specimens are, therefore, similar to the holotype astragalus of $P$. pacifica $(0 \cdot 65)$, and are somewhat wider than that of Acrophoca longirostris (0.62), although it has not been possible to examine the full range of variation in these species. The specimens are otherwise almost indistinguishable from those of $P$. pacifica.

Calcaneum. MNHN CHL35 is a left calcaneum (Pl. 2, fig. 9). The specimen is in fair condition but is covered by matrix over the lower astragalar and cuboid articular facets, and some prominent areas are abraded. As with the astragalus, the calcaneum is indistinguishable from that of $P$. pacifica, with the exception that, although damaged, the distal region of the medial surface is shorter. This is most apparent in dorsal view, where the distal medial surface of the astragalus of $P$. pacifica expands level with the distal quarter of the sustentacular facet. In MNHN CHL35, this expansion occurs level with the end of the facet. 


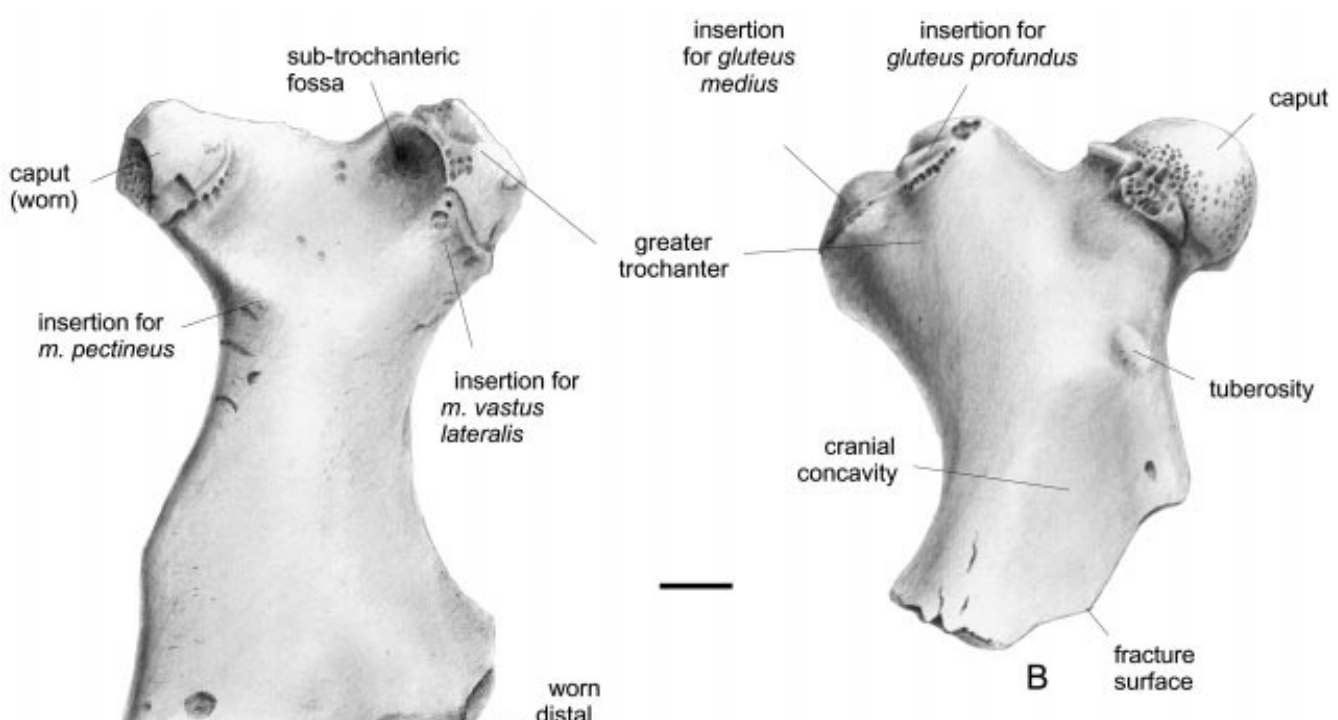

A

distal

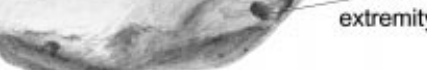
tendinus $m$. flexor hallucis longus
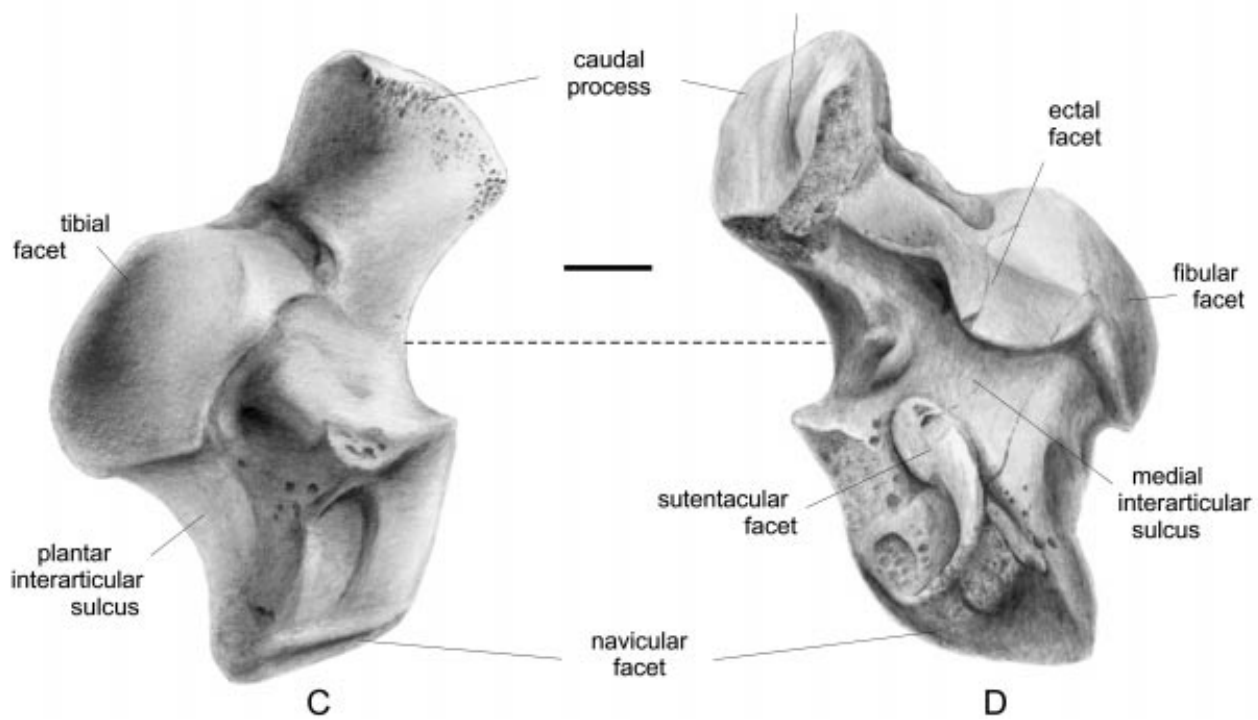

TEXT-FIG. 5. Piscophoca sp. material. A, right femur (MNHN CHL18) in caudal aspect. B, right femur (MNHN CHL17) in cranial aspect. Right astragalus (MNHN CHL37) in C, lateral, and D, medial aspects. Scale bars represent $10 \mathrm{~mm}$.

\section{Indeterminate Monachinae}

The following specimens are referable to the Monachinae, but lack diagnostic features that would allow more precise identification.

Material. Four left humeri (MNHN CHL2-4, 42), four right humeri (MNHN CHL40, 43-45), two right metatarsal 1 (MNHN CHL54, 56), metatarsal 1? (MNHN CHL53), left metatarsal 2 (MNHN CHL55), left metatarsal 5 (MNHN 


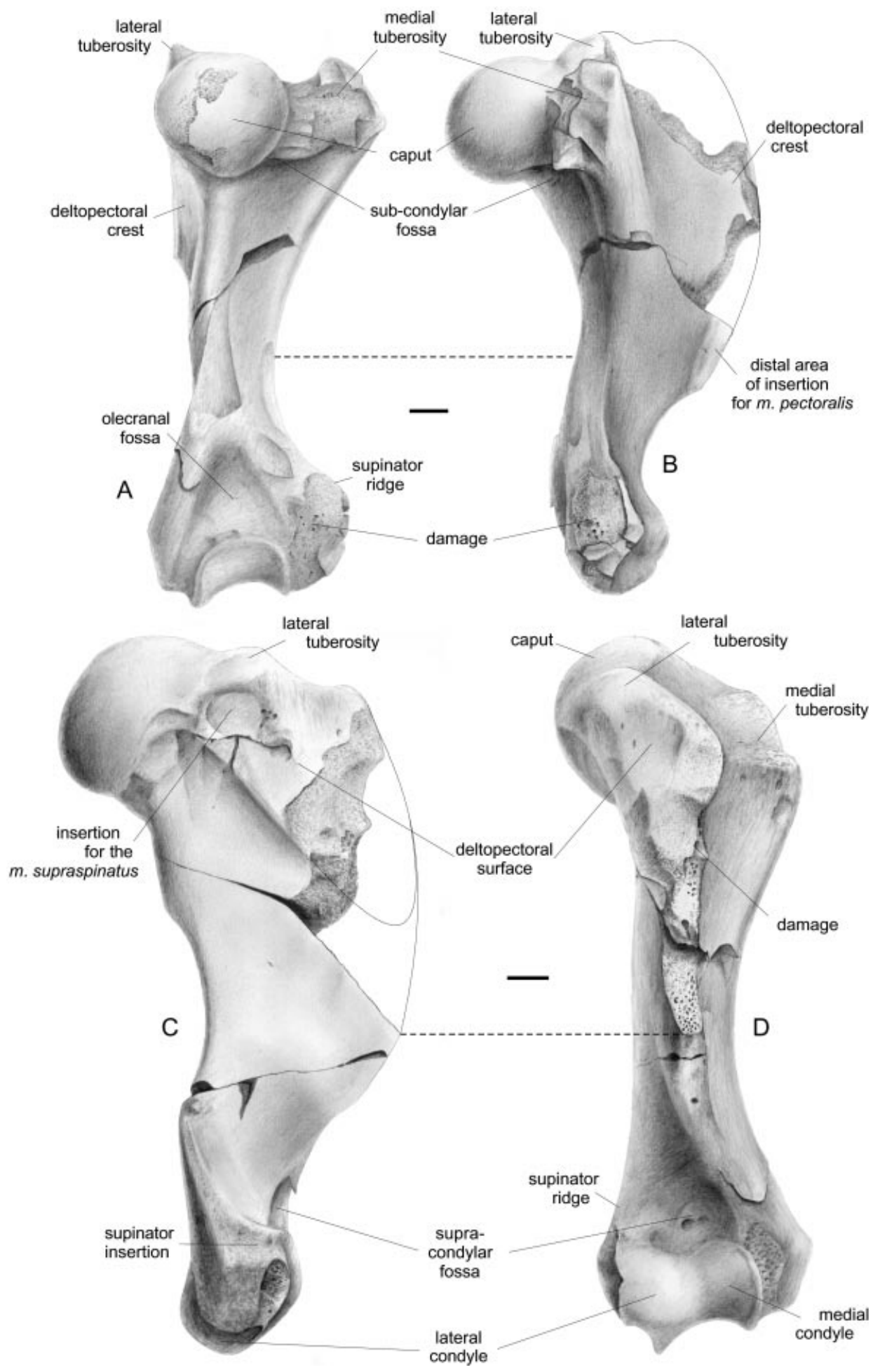


CHL52), three metacarpal 3 (MNHN CHL46-47, 49), right metacarpal III (MNHN CHL48), first carpal phalanx (MNHN CHL50), second carpal phalanx (MNHN CHL51), indeterminate phalanx (MNHN CHL57).

\section{Description}

Humerus. The eight humeri vary considerably in size and, grouped on this basis, the possibility exists that up to three species may be present. However, the humeri are osteologically homogeneous, and it is equally likely that the size variation inherent in this sample is a result of sexual dimorphism or ontogeny. Considerable sexual dimorphism is characteristic of pinnipeds (King 1983; see Bininda-Emonds and Russell 1996). None of these specimens exhibits features that readily permit referral to either Acrophoca or Piscophoca (but see below).

Two damaged, but almost complete humeri have been recovered (MNHN CHL3, left; MNHN CHL40, right: Textfig. 6A-D). Information missing from these can be obtained from the other fragments (e.g. MNHN CHL2, 45). MNHN CHL3 is $119 \mathrm{~mm}$ long, and is complete except for damage to the deltopectoral crest, the diaphysis and the medial distal condyle. MNHN CHL40 is $166 \mathrm{~mm}$ long, and is missing the same regions as MNHN CHL3. However, the medial distal condyle, medial tuberosity and medial side of the head in this specimen are all worn. The shaft is slender, and rather more like that of Acrophoca than Piscophoca. The head is directed dorsally and caudally, such that the acute angle formed by the intersection of the base of the head and the long axis of the bone is approximately 40 degrees. The diameter of the head is one-quarter the total length of the bone. A sub-condylar fossa is variably developed on the caudal surface. With the exception of the Bahía Inglesa humeri, the only monachines to exhibit this character are Piscophoca and its apparent ancestor, Monotherium aberratum (Muizon 1981a, 1982). However, a number of characters in the Bahía Inglesa specimens differ markedly from those seen in Piscophoca and M. aberratum.

The height of the medial tuberosity is also variable, but is generally the same height or slightly lower than the head. The lateral tuberosity is well developed, and is notable because it rises slightly higher than the head in all specimens where this feature is preserved. This condition was considered primitive by Muizon and Hendey (1980), as it is found in 'Monotherium' and in most terrestrial carnivorans (Muizon and Hendey 1980). Although not as well developed as that seen in the Otariidae, the development of the lateral tuberosity nevertheless results in the formation of a right angle on the proximal surface of the deltopectoral crest. The lateral tuberosity and the deltopectoral crest are strongly medially directed, resulting in a somewhat narrow and deep sulcus between the two tuberosities.

The deltopectoral crest itself is typically monachine in that it curves smoothly into the shaft approximately onequarter of the length of the humerus from the distal extent of the distal condyles (King 1983; Wyss 1988). The crest is unlike either Acrophoca or Piscophoca in that it is short and triangular in lateral view owing to the development of the lateral tuberosity (MNHN CHL2), very much as in M. shauinslandi. In Acrophoca, the crest is long and narrow in lateral aspect, such that in this view, maximum width of the bone is achieved at the midpoint. Furthermore, on the lateral surface the caudal margin of the crest meets the long axis of the diaphysis at an acute angle of 42 degrees. In Piscophoca, this angle is 60 degrees, and the distal extent of the crest results in maximum thickness being achieved one-third of the length of the bone from the proximal tip. The Bahía Inglesa material is somewhat intermediate between Acrophoca and Piscophoca; maximum width occurs one-quarter of the length from the proximal tip, and the diaphyseal long axis and caudal margin of the crest intersect at 42 degrees. Unlike 'Monotherium', Homiphoca and phocines, no entepicondylar foramen is present. However, a supinator ridge is developed and forms an angle where it joins the shaft at its proximal extent, level with the distal extent of the deltopectoral crest. This ridge is much better developed than in either Acrophoca or Piscophoca, and appears to be as well developed as that in Homiphoca (Muizon and Hendey 1980). However, the crest is not expanded laterally, and therefore does not approach the expansion seen in phocines like Phoca and Erignathus. We suggest that the character state in MNHN CHL3 and 40 exhibits the primitive phocid character state, in contrast to some other monachines (Wyss 1988).

Podials. Elements of the pinniped pes and manus are generally poorly diagnostic at higher level, and are not described here. However, such material can often be referred to subfamilial level and these specimens are referred to the Monachinae on the basis of possession of either (1) smooth, un-notched articular facets, (2) weak trochlear articulations, or (3) extreme dorsoventral flattening (King 1966; Wyss 1988).

TEXT-FIG. 6. Left humerus (MNHN CHL3) in A, caudal, and B, medial aspects. Right humerus (MNHN CHL40) in C, lateral, and D, cranial aspects. Scale bars represent $10 \mathrm{~mm}$. 
Material. Premolar (MNHN CHL82), ulna (MNHN CHL38), left innominate (MNHN CHL62), five cervical vertebrae (MNHN CHL21, 61, 64-65, 67), two dorsal vertebrae (MNHN CHL63, 69), two lumbar vertebrae (MNHN CHL66, $68)$.

Remarks. The presence of a pectineal tuberosity on the innominate indicates that it is from a phocid (Muizon and Hendey 1980). Whether monachine characters such as a cranial fossa on the ilium or an obturator foramen are present on the lateral surface (Wyss 1988) cannot be determined at present because it is obscured by matrix. The vertebrae are tentatively referred to the Phocidae based on the development of the neural spine and lateral processes, which are proportionally smaller in phocids than in otariids (King 1983).

\author{
Indeterminate Pinnipedia
}

Material. Right femur (MNHN CHL16), two left tibiae (MNHN CHL58, 60), two dorsal vertebrae (MNHN CHL71, 75), right calcaneum (MNHN CHL59), left navicular (MNHN CHL8), three caudal vertebrae (MNHN CHL26-28), metatarsal I? (MNHN CHL70), indeterminate metatarsal (MNHN CHL76), first phalanx? (MNHN CHL77), second phalanx (MNHN CHL72), three sternal segments (MNHN CHL6-7, 73), eleven rib fragments (MNHN CHL9-13, 15, $63,74,78-79,81)$.

Remarks. The tibiae are clearly pinniped because the tibia and fibula were fused proximally (Wyss 1988). They probably belong to a phocid. The remaining specimens are either too poorly preserved or undiagnostic to permit useful description, and have been identified as pinniped on the basis of overall morphology.

\title{
DISCUSSION
}

All of the diagnostic pinniped material recovered from Bahía Inglesa is referable to the Phocidae; otariids and odobenids are absent. At least two phocid genera are present, but the possibility exists that more than two species may be represented. Until articulated or better-associated material is recovered, this possibility remains untestable.

The majority of pinniped material recovered from Bahía Inglesa is referable to the Monachinae. Fossil monachines are known from the Middle Miocene of eastern USA (Ray 1976a, $b$ ) and Argentina (Muizon and Bond 1982), the Upper Miocene of Belgium (Muizon 1982), eastern Europe (Koretsky 1999), Peru (Muizon 1981a), and Algeria (Muizon 1981b), and Pliocene of Carolina and California, USA (Ray 1976a), Peru (Muizon 1981a), South Africa (Muizon and Hendey 1980), France and Italy (Ray 1976a).

The palaeobiogeography and taxonomic status of the Monachinae has been the subject of considerable recent debate. Although the Phocidae is considered monophyletic (e.g. Muizon 1982; Wyss 1988; Bininda-Emonds and Russell 1996; Bininda-Emonds et al. 1998, 1999; Adam and Berta 2000), the status of its two constituent groups Phocinae and Monachinae is less certain.

Wyss (1988) reviewed the characters that define these groups and found that apart from a number of character 'tendencies', the Monachinae is largely supported by shortening of metatarsal 3, reduction of claws on the pes, premaxilla-maxilla suture located within the nasal aperture, and reduction in the number of upper incisors. Of these, only the reduction of hind-limb claws is unique to monachines and Wyss (1988) concluded that the group is paraphyletic with respect to the Phocinae, forming a series of basal sister-groups to this clade. Furthermore, in his cladistic analysis, Wyss (1988) found Monachus to be paraphyletic, with both $M$. monachus and $M$. tropicalis closer to other phocids than to M. shauinslandi. This hypothesis would support the view of many authors (e.g. King 1966; Ray 1976a; Muizon and Hendey 1980; Muizon, 1981a, 1982) that the Monachinae are the most primitive phocids, and that Monachus in particular is the most primitive genus of the subfamily. 
Wyss' hypothesis has been the subject of contention within the systematic literature (Berta and Wyss 1994; Bininda-Emonds and Russell 1996; Bininda-Emonds et al. 1998, 1999; Koretsky 1999). The present outcome of these studies is that monophyly of both Monachus and the Monachinae is apparently defensible when subjected to parsimony analysis. In view of these findings we do not follow Wyss' (1988) conclusions and regard both Monachus and Monachinae as clades. Bininda-Emonds and Russell (1996) and Bininda-Emonds et al. (1998) found that lobodontins and monachins form a clade in which Monachus is the most recently evolved taxon. In a more recent study, Bininda-Emonds et al. (1999) rejected the hypothesis of lobodontin paraphyly and found Monachus to be basal to the lobodontins. Although we have not yet performed a parsimony analysis, our own study leads us to favour this view. Muizon (1981a) originally referred both A. longirostris and P. pacifica to the Lobodontini and we follow this arrangement here.

The Bahía Inglesa monachines have implications for phocid dispersal in the Pacific, of which there are several interpretations. Fordyce (1989) emphasized the possibility that all southern phocids were part of an endemic Southern Hemisphere radiation. He implied that the view of several independent 'invasions' of the south by Northern Hemisphere phocids favoured by some palaeontologists (e.g. Muizon and Hendey 1980; Muizon 1982), simply reflected the longer history of collection and discovery in the Northern Hemisphere (Fordyce 1989). Cognisant of Fordyce's (1989) critique, we favour the several independent lobodontin migrations proposed by Muizon and Hendey (1980) and Muizon (1982) because compelling evidence for a contradictory alternative is lacking. We recognize that a phylogenetic analysis using parsimony might provide an explicit interpretation of the relatedness between the species involved, and that this might provide a testable biogeographical framework. Such an undertaking is beyond the scope of the present paper however, as we have been unable to examine some of the key fossil taxa involved. Our discussion here is, therefore, based on a review of the existing literature.

Monachines were present on both sides of the Atlantic by the middle Miocene, and became dominant in the North Atlantic during the late Miocene and Pliocene (King 1983). Monachine species referred to 'Monotherium' are the earliest known monachines and were already present on the east coast of North America around 14 Ma (King 1983). Muizon (1982) considered Monotherium aberratum to be a lobodontin, and the ancestor of Piscophoca. This implies a southern route of migration (Text-fig. 7A). Since the earliest monachine in the Pisco Formation (an undescribed species related to P. pacifica) is from sediments of Middle Miocene age (Muizon and DeVries 1985), this migration must have taken place in the Middle Miocene or earlier. The occurrence of Acrophoca sp. in probable Late Miocene sediments of the Bahía Inglesa Formation demonstrates the presence of lobodontins $1600 \mathrm{~km}$ further south along the Pacific coast of South America at this time.

Muizon $(1981 a$, 1982) considered A. longirostris to be related to Hydrurga, but not ancestral to this genus because of its high level of specialization. The ancestor of Acrophoca, and hence Hydrurga, may therefore have already been present on the Pacific coast of South America by the Late Miocene. By comparison, the lobodontin Homiphoca was regarded as ancestral to Lobodon by Muizon and Hendey (1980), and was possibly present on both the South Atlantic coast of South Africa and Argentina in the Late Miocene and Early Pliocene. The specific identity of the South American material is questionable, though Muizon and Hendey (1980) regarded it as similar to H. capensis. It has been suggested (e.g. Muizon 1982) that lobodontins may have migrated from South America to Africa via the Antarctic Current. Even if they were already present on the African Atlantic coast this theory is plausible, as the direction of the Antarctic Current would have served to impede an east to west migration (Muizon and Hendey 1980).

Because it would presumably have been easier to cross to Antarctica from Tierra del Fuego than from South Africa, the ancestors of the Lobodon-Hydrurga group of Muizon and Hendey (1980) and Muizon (1982) seem more likely to have followed the west and east coasts of South America respectively, with perhaps one migration to Africa via the Antarctic Current (Text-fig. 7A). The fossil pinniped material of Bahía Inglesa provides important additional data regarding the radiation of the lobodontins into the Antarctic.

The Bahía Inglesa Acrophoca appears to have been slightly smaller than A. longirostris, but as the full range of variation cannot be judged from our sample this size difference may be ontogenetic. Data 

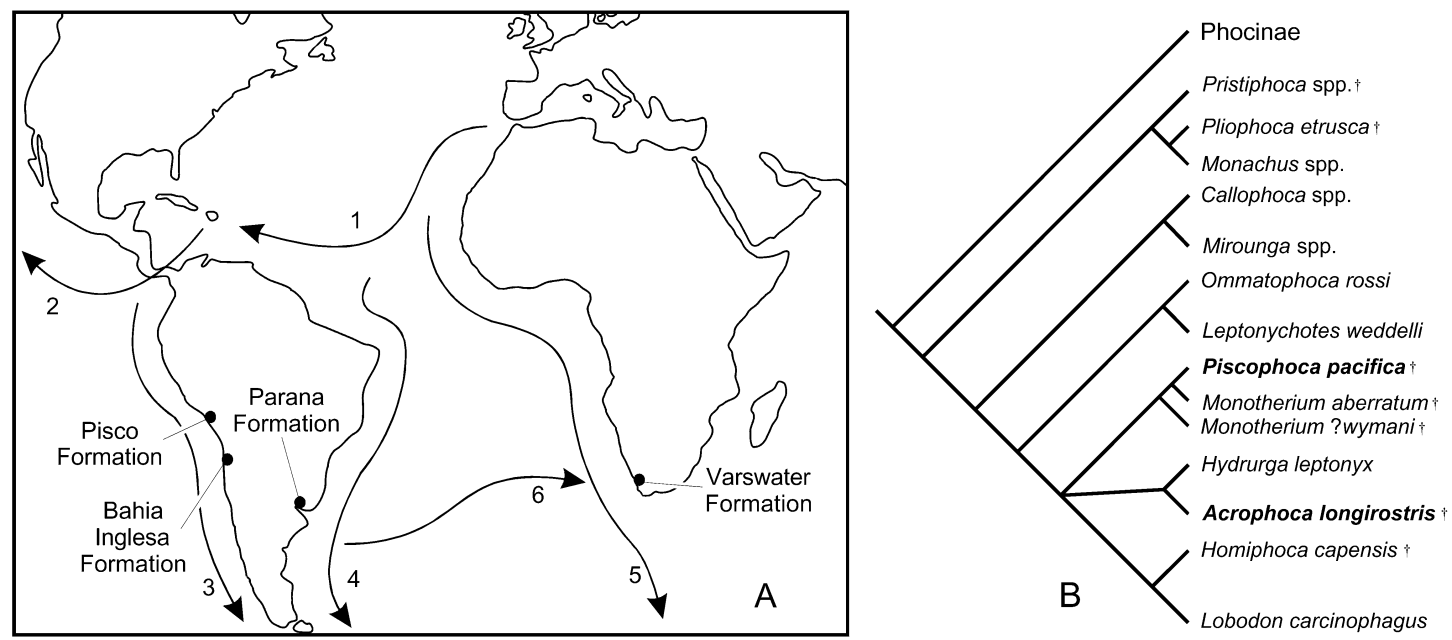

TEXT-FIG. 7. Radiation and phylogeny of monachine phocids. A, possible routes of radiation for monachines with locations of other Southern Hemisphere monachine-bearing locations; modified after Muizon (1982). 1, migration of Monachini tribe of Monachinae via equatorial currents. 2, migration of Monachini to Hawaiian Islands (Monachus schauinslandi). 3, migration of Lobodontini to Antarctica via Peru and Chile (Acrophoca and Piscophoca). 4, migration of Lobodontini to Antarctica via Argentina (Properiptychus and Homiphoca?). 5, migration of Lobodontini to Antarctica via Africa (Homiphoca). 6, potential migration of Argentine monachines to Africa via Antarctic Current. B, Phylogenetic relationships of living and fossil Monachinae adopted in this work (after Muizon 1982). $†$ indicates extinct taxa.

obtained from the associated postcrania cast little light on how specialized the Chilean Acrophoca was. However, the deep caudal and cranial tibial fossae found on MNHN CHL31 may be interpreted as advanced features, probably related to increased specialization for aquatic locomotion (Wyss 1988). A. longirostris was thought by Muizon (1981a) to be a primarily littoral form. MNHN CHL31 may suggest that the Chilean Acrophoca was better suited for swimming in open waters. However, the concavity of the proximal tibial facets is like that of the Phocinae rather than that of the southern phocids, and therefore probably represents a primitive character.

The mandibular fragment (MNHN CHL5) shows a tooth morphology that is intermediate between A. longirostris and Monachus. The teeth of MNHN CHL5 have a much greater cusp development than A. longirostris, but are less robust than their nearest morphological match, $M$. shauinslandi. The narrow ramus and significant dental diastemata are less pronounced (and therefore less derived) than in A. longirostris, and the sigmoidal shape of the ramus seen in dorsal view indicates that although narrow, the mandible must have been significantly shorter than in that species. It is also possible that the lateral compression and complexity of the cusp pattern could form the basis of the derived dentition seen in Hydrurga, and it is, therefore, not impossible that, although not directly ancestral, MNHN CHL5 is of a species of Acrophoca much closer to Hydrurga than A. longirostris.

Compared with Acrophoca, Piscophoca material from Bahía Inglesa is more abundant, and much of the material referred to indeterminate Monachinae is probably referable to this genus. The mandibular ramus is intermediate between Monachus monachus and P. pacifica, and may, therefore, be considered somewhat primitive overall. Although the reduction of $\mathrm{C}_{1}$ may be a derived character reflecting prey preference, none of the postcrania exhibits characteristics that may reasonably be interpreted as derived compared with $P$. pacifica. In addition, many of the characters are those normally associated with the phocines and Monachus, and therefore less modified than those of the Lobodontini. Phocine characters present in the Chilean material include prominent insertion for $\mathrm{m}$. anconeus medialis on the ulna; presence of deep subtrochanteric fossa and height of greater trochanter on femur; long sustentacular facet on astragalus and caudally visible transverse foramen on atlas. 
The eight humeri are probably referable to Piscophoca because MNHN CHL40 was collected less than two metres from MNHN CHL41 (ramus), and the abundance of humeri is consistent with the abundance of probable Piscophoca material. In addition, apart from the slender shaft, these humeri bear many plesiomorphies consistent with the somewhat primitive postcrania tentatively referred to Piscophoca. In particular, the presence of a variably developed sub-condylar fossa, otherwise seen only on $P$. pacifica and M. aberratum, is strong evidence of referral to Piscophoca. Absence of an entepicondylar foramen was considered primitive by Muizon and Hendey (1980), but derived by Muizon (1982) and Wyss (1988), although interpretation of the polarity of this character probably centres on the choice of outgroup (Wyss 1988). However, its presence in Monotherium aberratum, the presumed ancestor of Piscophoca, and absence in any extant monachine indicates that, for monachines at least, absence of this foramen is a derived character. Nevertheless, the presence of such plesiomorphies as a supinator ridge and high lateral tuberosity common in terrestrial carnivorans (Muizon and Hendey 1980), suggests that these humeri are less derived than the humerus of $P$. pacifica.

The Phocinae responded to the climatic deterioration of the late Neogene by specialization to cooler temperatures and by a north-south expansion of their geographic range (King 1983). Ray (1976a) suggested that absence of a Southern Hemisphere phocine radiation was due to their inability to cross the warmer equatorial waters, though competition from existing southern monachines could also have been a factor. By comparison, global cooling appears to have driven the Monachinae into warmer, more equatorial regions, and they were evidently able to radiate into the Pacific very early in their evolution. Fossils of Ommatophoca are known from the Pliocene of New Zealand (King 1973) and those of Lobodon from the Pleistocene of Africa (McKenna and Bell 1997). Excepting the fossil taxa already mentioned, other lobodontins appear to lack a fossil record. This suggests that the Antarctic spread of lobodontins is a geologically recent phenomenon. However, Fordyce (1989) suggested that the extant lobodontin genera may have appeared as early as the Miocene.

Both the vertebrate and invertebrate fauna of the Pisco Formation indicate a warm-water or even tropical environment (Muizon and DeVries 1985). The abundance of the Monachinae in the formation is consistent with the thermophilic tendencies shown by the fossil and Recent distribution of the group. The presence of Acrophoca and Piscophoca in this fauna indicates that these species must have at least been warm-water tolerant. Characteristic warm-water teleosts (Istiophoridae) and chondrichthyans (e.g. Carcharhinus spp., Heterodontus, Isogomphodon) are present in the Bahía Inglesa assemblage, as are crocodyliforms (Walsh 1999). Piscophoca in particular shares many similarities with Monachus, a genus that is today restricted to Mediterranean or tropical waters. However, although monachines may be able to tolerate tropical environments, they nevertheless experience difficulty in thermoregulation when on land (Whittow 1984). Furthermore, the historical distribution of Monachus may have resulted from some other cause such as interspecific competition.

In Peru, the replacement of monachines by otariids appears to have occurred some time after the appearance there of the latter in the early Pliocene. This faunal replacement is parallelled in South Africa (Olson 1983). Given the probable thermophilic requirements of the late Neogene Monachinae, one possible cause of this replacement is climatic cooling and its associated ecological effects. Nevertheless, unless they were the only monachines to have been capable of living in cold waters, the Antarctic lobodontins are a notable exception to this. A more likely explanation for the replacement of phocids by otariids along the coast might relate to the terrestrial mobility of otariids, and their ability to traverse steep rocky shores. One apparent exception to this pattern is Mirounga, the only phocid that routinely lives alongside otariid species (King 1983; Bonner 1994). Notably, Mirounga is regarded as the most terrestrial of extant phocids (e.g. Siniff 1991). A significant rise in sea level might have reduced the available area of shallow sloping shoreline required by the less terrestrially mobile phocids for haul-outs and breeding. The flat, icy habitat of the Antarctic monachines could possibly explain their persistence in the Southern Hemisphere.

\section{CONCLUSIONS}

Although fossil pinnipeds have been reported from Peru and Argentina, the Bahía Inglesa Formation represents the first occurrence of the group in Chile. This assemblage therefore provides valuable data 
concerning the timing and route of the monachine radiation in the Southern Hemisphere. The presence of two genera known previously only from Peru, Acrophoca and Piscophoca, is confirmed by the presence of diagnostic cranial elements. The true pinniped diversity at the site is likely to be higher. Significant differences observed between the type species of Acrophoca and Piscophoca and our new Chilean material suggests to us that these specimens represent new species, though we also note the possibility of sexual or ontogenetic variation. We have elected not to name these possible new species at this time because new Peruvian material of both Acrophoca and Piscophoca is under description and new species, represented by substantial remains, have been recovered (Muizon, pers. comm. 2000). Conceivably, our material may prove referable to these new species.

Further collection from this and other fossiliferous sites of similar age along the central and northern Chilean coast will probably increase our knowledge of pinniped diversification around South America during this important period in seal evolution.

Acknowledgements. We thank Dr D. Martill (Portsmouth University) for discussion; Dr C. Muizon (Muséum national d'Histoire naturelle, Paris) for critical discussion, helpful comments on the manuscript and access to specimens; Dr S. Evans (University College London) for editorial assistance; Dr E. Fordyce (University of Otago, New Zealand), Dr J. McKee (Palmerston North, New Zealand) and Dr L. Barnes (Natural History Museum of Los Angeles County, California) for discussion; Dr E. Frey (Staatliches Museum für Naturkunde, Karlsruhe) and Dr P. Jenkins (The Natural History Museum, London) for access to specimens, D. Ward for help with shark identification and discussions on shark biostratigraphy, and R. Loveridge (Portsmouth University) for photography. Professor Guillermo Chong (Universidad Catolica del Norte, Chile) is thanked for his logistical help, and Dr Peter Turner (Birmingham University) for the use of his vehicle in Chile. This work was supported by a University of Portsmouth Bursary, and by bursaries from the Percy Sladen Memorial Fund and the John Ray Trust.

\section{REFERENCES}

ADAM, P. J. and BERTA, A. 2000. Phylogenetic analysis of the Pinnipedimorpha (Mammalia) with an analysis of locomotor and feeding evolution. Journal of Vertebrate Paleontology, 20 (Supplement to No. 3), 25A.

BERTA, A. and wYSS, A. R. 1994. Pinniped phylogeny. 33-56. In BERTA, A. and DEMERE, T. A. (eds). Contributions in marine mammal paleontology honouring Frank C. Whitmore, Jr. Proceedings of the San Diego Society of Natural History 29, California, $268 \mathrm{pp}$.

BININDA-EMONDS, O. R. P., BRYANT, H. N. and RUSSELL, A. P. 1998. Supraspecific taxa as terminals in cladistic analysis: implicit assumptions of monophyly and a comparison of methods. Biological Journal of the Linnean Society, 64, $101-133$.

— and RUSSELL, A. P. 1996. A morphological perspective on the phylogenetic relationships of the extant phocid seals (Mammalia: Carnivora: Phocidae). Bonner Zoologische Monographien, 41, 1-256.

- GitTLEMAN, J. L. and PURVIS, A. 1999. Building large trees by combining phylogenetic information: a complete phylogeny of the extant Carnivora (Mammalia). Biological Reviews, 74, 143-175.

BONNER, W. N. 1989. The natural history of seals. Christopher Helm, London, 196 pp.

— 1994. Seals and sea lions of the world. Blandford Press, London, 224 pp.

DARWIN, C. 1891. Geological observations on the volcanic islands and parts of South America visited during the voyage of H.M.S. 'Beagle', $3^{\text {rd }}$ Edition. Smith Elder and Co., London, 648 pp.

DATHE, F. 1983. Megaptera hubachi n. sp., ein fossiler Bartenwal aus marinen Sandsteinschichten des tieferen Pliozän Chiles. Zeitschrift für Geologische Wissenschaften, 11, 813-848.

DONOSO-BARROS, R. 1975. Contribucion al conocimiento de los cetaceos vivientes y fosiles del territorio de Chile. Gayana Zoologia, 36, 1-127.

FLYNN, J. J. and WYSS, A. R. 1998. Recent advances in South American mammalian paleontology. Trends in Ecology and Evolution, 13, 449-454.

FORDYCE, R. E. 1989. Origins and evolution of Antarctic marine mammals. 269-281. In CRAME, J. A. (ed.). Origins and evolution of the Antarctic biota. Geological Society, London, Special Publication, 47, 322 pp.

GLYCKMAN, L. S. 1964. Akuly paleogena i ikh stratigraficheskoye znacheniye [Palaeogene sharks and their stratigraphic significance]. Akademii Nauk SSSR, Moscow, 228 pp.

GOOD, D. A. 1984. The phylogenetic position of fossils assigned to the Gerrhonotinae (Squamata: Anguidae). Journal of Vertebrate Paleontology, 8, 188-195. 
GRAY, J. E. 1825. An outline of an attempt at the disposition of Mammalia into tribes and families with a list of the genera apparently appertaining to each tribe. Annalia Philosophica London, 26, 337-344.

- 1869. Catalogue of carnivorous, pachydermatous, and edentate Mammalia in the British Museum. British Museum (Natural History), London, 398 pp.

HENDEY, Q. B. and REPPENING, C. A. 1972. A Pliocene phocid from South Africa. Annals of the South African Museum, 59, 71-98.

HERM, D. 1969. Marines Pliozän und Pleistozän in Nord- und Mittel-Chile unter besonderer Berücksichtigung der Entwicklung der Mollusken-Faunen. Zitteliana, 2, 1-159.

IBARAKI, M. 1995. Neogene chronostratigraphy of biosiliceous sediments on the Pacific coast of South America based on planctonic foraminifera. Reports of the Faculty of Science, Shizuoka University, 29, 63-71.

ILliger, J. C. W. 1811. Prodomus systematics mammalium et avium. C. Salfeld, Berlin, 302 pp.

KING, J. E. 1966. Relationships of the hooded and elephant seals (genera Crystophora and Mirounga). Journal of Zoology, 148, 385-398.

1972. Observations on phocid skulls. 81-115. In HARRISON, R. J. (ed.). Functional anatomy of marine mammals. Academic Press, London, $451 \mathrm{pp}$.

1973. Pleistocene Ross seal (Ommatophoca rossi) from New Zealand. New Zealand Journal of Marine and Freshwater Research, 7, 391-397.

— 1983. Seals of the World. British Museum (Natural History), London, and Oxford University Press, Oxford, 240 pp.

KORETSKY, I. 1999. The fossil monk seal Pontophoca sarmitica (Mammalia: Phocidae: Monachinae) from the Miocene of Eastern Europe. Journal of Vertebrate Paleontology, 19 (Supplement to No. 3), 57A.

LONG, D. J. 1993. Late Miocene and Early Pliocene fish assemblages from the north central coast of Chile. Tertiary Research, 14, 117-126.

MARSHALL, L. G. 1990. Fossil Marsupialia from the type Friasian land mammal age (Miocene), Alto Rio Cisnes, Aisen, Chile. Revista Geologica de Chile, 17, 19-55.

MCKENNA, M. C. and BELL, S. K. 1997. Classification of mammals above the species level. Columbia University Press, New York, xi + 631 pp.

MUIZON, C. DE 1981a. Les vertébrés fossiles de la Formation Pisco (Pérou). Première partie. Travaux de l'Institut Français d'Études Andines, 22, 1-161.

— 1981b. Premier signalement de Monachinae (Phocidae, Mammalia) dans le Sahélien (Miocène supérieur) d'Oran (Algérie). Palaeovertebrata, 11, 181-194.

1982. Phocid phylogeny and dispersal. Annals of the South African Museum, 89, 175-213.

- 1984. Les vertébrés fossiles de la Formation Pisco (Pérou) II. Les odontocètes (Cetacea, Mammalia) du Pliocène inférieur de Sud-Sacaco. Travaux de l'Institut Français d'Études Andines, 27, 1-188.

— 1987. The affinities of Notocetus vanbenedeni, an Early Miocene Platanistoid (Cetacea, Mammalia) from Patagonia, southern Argentina. American Museum Novitates, 2904, 1-20.

— 1988. Les vertébrés fossiles de la Formation Pisco (Pérou) III. Les odontocètes (Cetacea, Mammalia) du Miocène. Travaux de l'Institut Français d'Études Andines, 42, 1-244.

- and HENDEY, Q. B. 1980. Late Tertiary seals of the South Atlantic ocean. Annals of the South African Museum, 82, $91-128$.

— and BOND, M. 1982. Le Phocidae (Mammalia) miocène de la formation Paraná (Entre Ríos, Argentine). Bulletin du Muséum National d'Histoire Naturelle, Paris, $4^{i e ̀ m e}$ Série, Section C, 4, 165-207.

— and DEVRIES, T. J. 1985. Geology and paleontology of late Cenozoic marine deposits in the Sacaco area (Peru). Geologische Rundschau, 74, 547-563.

OLSON, S. L. 1983. Fossil seabirds and changing marine environments in the late Tertiary of South Africa. South African Journal of Science, 79, 399-402.

PASCUAL, R. and JAUREGUIZAR, E. O. 1990. Evolving climates and mammal faunas in Cenozoic South America. Journal of Human Evolution, 19, 23-60.

PILlERI, G. (ed.) 1989. Beiträge zur Paläontologie der Cetaceen Perus. Hirnanatomisches Institut der Universität, Bern, $228 \mathrm{pp}$.

RAY, C. E. 1976a. Geography of phocid evolution. Systematic Zoology, 25, 391-406.

— 1976b. Phoca wymani and other Tertiary seals (Mammalia: Phocidae) described from the Eastern Seaboard of North America. Smithsonian Contributions to Paleobiology, 6, 1-36.

ROJO, M. A. 1985. Un aporte al conocimiento del Terciario marino: Formacion Bahía Inglesa. Actas Congreso Geologico Chileno, 4, 1.514-1.533.

SALINAS, P. 1988. Hallazgo de cetaceos fosiles (Mysteceti, Balaenopteridae) en la ciudad de Coquimbo, Chile. Revista Geologica de Chile, 15, 89-94. 
SCHEFFER, V. B. 1958. Seals, sea lions and walruses; a review of the Pinnipedia. Stanford University Press, Stanford, $179 \mathrm{pp}$.

SINIFF, D. B. 1991. An overview of the ecology of Antarctic seals. American Zoologist, 31, 143-149.

TSUCHI, R., SHUTO, T., TAKAYAMA, T., FUJIYOSHI, A., KOIZUMI, I., IBARAKI, M. and MARTINEZ, P. R. 1988. Fundamental data on Cenozoic biostratigraphy of Chile. Reports of Andean Studies, Shizuoka University-Trans-Pacific Correlation of Cenozoic Geohistory, 2, 1-108.

VALENZUELA, E. and BRITO, J. L. 1994. Procedencia y datacion preliminar de un delfinido fosil del genero Globicephala. Actas Congreso Geologico Chileno, 7, 548-550.

VAN BENEDEN, P. J. 1877. Description des Ossements fossiles des environs d'Anvers, première partie: Pinnipedes ou Amphithériens. Musée Royal d'Histoire Naturelle de Belgique, Annales, 1, 88 pp.

VENGLINSKIY, I. V. 1989. O novoy nakhodke zuba miotsenovykh akul Cosmopolitodus hastalis (Agassiz) [New find of a tooth of the Miocene shark Cosmopolitodus hastalis (Agassiz)]. Paleontologicheskiy Sbornik (L'vov), 26, 96-97.

WALSH, S. A. 1999. A new Mio-Pliocene marine bone-bed from north-central Chile. Journal of Vertebrate Paleontology, 19 (Supplement to No. 3), 82A.

- and HuME, J. P. 2001. A new Neogene marine avian assemblage from north-central Chile. Journal of Vertebrate Paleontology, 21, 484-491.

whitTow, G. C. 1984. Physiological ecology of the Hawaiian monk seal (Monachus schauinslandi). National Geographic Society, Research Reports, 17, 937-941.

WYSS, A. R. 1988. On 'retrogression' in the evolution of the Phocinae and phylogenetic affinities of the monk seals. American Museum Novitates, 2924, 1-38.

CHARRIER, R. and FlynN, J. J. 1996. Fossil mammals as a tool in Andean stratigraphy; dwindling evidence of Late Cretaceous volcanism in the south central Main Range. PaleoBios, 17, 13-27.

- FlYNN, J. J. and CHARRIER, R. 1994. Yet two additional fossil mammal faunas from the Abanico Formation of the Andean Main Range, Chile. PaleoBios, 16, 15.

Typescript received 21 February 2001

Revised typescript received 11 July 2001
STIG WALSH

DARREN NAISH

University of Portsmouth Palaeobiology Research Group School of Earth and Environmental Sciences

Burnaby Road

Portsmouth PO1 3QL, UK

e-mail stigwalsh@ravenknoll.fsnet.co.uk darren.naish@port.ac.uk 